\title{
PENGARUH PERSONALITY DAN SPIRITUALITAS DI TEMPAT KERJA TERHADAP KINERJA DOSEN DI MAKASSAR
}

\author{
Badaruddin $^{1}$, Fatmasari², \\ Institut Teknologi dan Bisnis Nobel Indonesia ${ }^{1}$ \\ Universitas Dipa Makassar ${ }^{2}$ \\ e-mail: badar@stienobel-indonesia.ac.id ${ }^{1}$, fatma.sari@dipanegara.ac.id ${ }^{2}$
}

\begin{abstract}
Abstrak
Penelitian ini dimaksudkan sebagai upaya akademik untuk melihat lebih lanjut mengenai kinerja dosen dan factor-faktor yang mempengaruhinya. Faktor personality merupakan factor terbaik yang digunakan memprediksi kinerja pegawai. Factor lain yang mempengaruhi kinerja adalah factor yang berhubungan dengan lingkungan kerja, yaitu Spiritualitas di Tempat Kerja.

Penelitian ini menggunakan pendekatan kuantitatif dan menerapkan penelitian survei untuk mengambil sampel dan menyebarkan kuesioner secara online sebagai alat pengumpulan data. Seluruh ekuesioner yang dikembalikan diverifikasi, dan jumlah responden akhir yang dijadikan data penelitian adalah 178 dosen. Teknik analisis data menggunakan bantuan SPSS. Uji F digunakan untuk menguji kelayakan model dan menunjukkan bahwa model ini layak digunakan untuk menjelaskan pengaruh variabel indenden pada dependen

Hasil penelitian menunjukkan bahwa personality berpengaruh positif dan signifikan terhadap kinerja dosen dengan nilai $\mathrm{t}$ sebesar 3,923 lebih besar dari 1,97 (t hitung > t tabel) dan nilai signifikansi 0,000< 0,05. Demikian juga workplace spirituality personality berpengaruh positif dan signifikan terhadap kinerja dosen dengan t hitung sebesar 16,22 lebih besar dari 1,97 (t hitung > t tabel) dan nilai signifikansi $0,000<$ 0,05 .
\end{abstract}

Kata kunci : Kepribadian, Spiritualitas di Tempat Kerja, Kinerja Dosen

\section{Abstract}

This research is intended as an academic effort to find out more about the performance of lecturers and the factors that influence it. Personality factor is the best factor used to predict employee performance. Another factor that affects performance is a factor related to the work environment, namely Workplace Spirituality.

This study uses a quantitative approach and applies survey research to take samples and distribute online questionnaires as a data collection tool. All returned e-questionnaires were verified, and the number of final respondents used as research data was 178 lecturers. The data analysis technique used SPSS assistance. The F test is used to test the feasibility of the model and shows that this model is feasible to use to explain the effect of the independent variable on the dependent.

The results showed that personality had a positive and significant effect on lecturer performance with a $t$ value of 3.923 which was greater than 1.97 ( $t$ count $>$ t table) and a significance value of $0.000<$ 0.05. Likewise, workplace spirituality personality has a positive and significant effect on lecturer performance with $t$ count of 16.22 greater than 1.97 ( $t$ count $>$ t table) and a significance value of $0.000<$ 0.05

Keywords : Personality, Workplace Spirituality, Lecturer Performance

\section{PENDAHULUAN}

Organisasi yang berhasil dan maju adalah organisasi yang memiliki sumber daya manusia dengan kinerja yang berkualitas. Oleh karena itu, Perguruan Tinggi sebagai sebuah organisasi, kinerjanya juga ditentukan oleh sumber daya yang bekerja di dalamnya, diantaranya adalah dosen. Sebagai pekerja organisasi, dosen dituntut untuk memenuhi tugasnya dan menunjukkan kinerja yang positif. Hal ini dikarenakan, dosen merupakan pemain sentral dalam organisasi perguruan tinggi. Kaitannya dengan itu, kinerja dosen dapat diartikan dengan keseluruhan kemampuan dan perilaku untuk 
memenuhi tugas dan fungsi dosen dalam melaksanakan tridharma perguruan tinggi yaitu pendidikan, pengajaran, penelitian, dan pengabdian masyarakat (Darman, 2017).

Dosen dituntut untuk dapat memperlihatkan kinerja yang baik. Namun harapan tersebut belum sepenuhnya dapat diaktualisasikan oleh dosen di perguruan tinggi. Manuel \& Asuquo (2010) menemukan bahwa sikap yang tidak diharapkan dan persepsi yang negative terhadap pekerjaan karena persoalan remunerasi dan jaminan pension yang dipandang tidak memadai. Sara R. Banfield \& McCroskey, (2006) menyatakan bahwa tantangan dalam mewujudkan profesionalisme dosen adalah tenaga edukatif yang berkinerja buruk dan prestasi kerja yang tidak sesuai dengan harapan. Masih banyak dosen yang belum optimal melaksanakan tridharma perguruan tinggi, belum bisa mencurahkan seluruh perhatiannya secara focus seratus persen pada pekerjaannya,

Tugas professional dosen disebutkan dalam Undang-undang No.14 Tahun 2005 tentang Guru dan Dosen pasal 6, yaitu : 1). Melaksanakan Pendidikan, penelitian dan pengembangan ilmu serta pengabdian pada masyarakat, 2). Merencanakan, melaksanakan proses pembelajaran serta menilai dan mengevaluasi hasil pembelajaran, 3). Meningkatkan dan mengembangkan kualifikasi akademik dan kompetensi secara berkelanjutan sejalan dengan perkembangan ilmu pengetahuan, teknologi dan seni.

Dalam rangka pelaksanaan tugas professional tersebut, Dikti memberikan pedoman beban kerja dosen yang harus dilaksanakan dalam satu semester. Beban kerja dosen merupakan tugas yang diberikan pimpinan perguruan tinggi kepada dosen untuk melaksanakan tugas tridharma perguruan tinggi dan atau tugas tambahan dalam masa tertentu yang diukur dalam satuan kredit semester, meliputi : 1). Bidang Pendidikan, 2) bidang penelitian, 3) bidang pengabdian kepada masyarakat serta 4) penunjang tridharma perguruan tinggi.

Penelitian ini dimaksudkan sebagai upaya akademik untuk melihat lebih lanjut mengenai kinerja dosen dan factor-faktor yang mempengaruhinya. Secara teoritik terdapat dua factor yang mempengaruhi kinerja individu dalam organisasi, yaitu factor personal (Motowidlo et al., 1997) dan situasi/lingkungan (Tett \& Burnett, 2003). Dengan demikian maka kinerja akan dipengaruhi oleh berbagai factor. Neal \& Griffin, (1999) menyatakan bahwa kinerja dipengaruhi oleh sejumlah variable yaitu ability, personality, kepemimpinan, attitude, karakteristik pekerjaan, pengetahuan dan keterampilan, motivasi, sikap rekan kerja dan kelompok.

Faktor personality merupakan factor terbaik untuk digunakan memprediksi kinerja individu. Kepribadian pegawai yang sesuai dengan pekerjaannya (person job-fit) merupakan salah satu factor yang berpengaruh terhadap kinerja organisasi. Oleh karena itu, semakin sesuai pekerjaan dosen dengan kepribadiannya, maka kepuasan yang dirasakan juga makin tinggi, dan memperkuat komitmennya 1 pada organisasi dan pada akhirnya akan meningkatkan kinerjanya (Darman, 2017).

Personality (kepribadian) yang dimiliki setiap orang berbeda-beda karena. Personality merupakan adalah karakteristik individu yang berpengaruh pada pikiran, emosional dan perilakunya (Jason Colquitt et al., 2019). Personality merupakan aspek psikologis penting dalam menentukan perilaku individu termasuk perilaku di tempat kerja. Kepribadian merupakan factor yang sangat berpengaruh terhadap keberhasilan seorang dosen dalam proses belajar mengajar dengan mahasiswa. Penelitian tentang kepribadian dalam hubungannya dengan kinerja telah banyak dilakukan. Penelitian Hogan et al., (1996) yang menghubungkan antara kepribadian dan kinerja menunjukkan bahwa secara garis besar sangat berarti. 
Pengaruh personality terhadap kinerja telah banyak diteliti. Dalam penelitian ini, pengukuran personality diadaptasi dari Mammadov (2021) yang melakukan penilaian tentang kekuatan hubungan antara ciri-ciri big five personality dan kinerja akademik. Lima faktor dari dimensi kepribadian seperti yang dikonseptualisasikan oleh Costa dan McCrae (1992) termasuk Neuroticism, Extraversion, Openness, Agreeableness dan Conscientiousness (Rothman \& Coetzer, 2003)

Neurotisisme (Neuroticism) adalah dimensi normal kepribadian yang menunjukkan kecenderungan umum untuk mengalami hal-hal negatif seperti takut, sedih, malu, marah, bersalah, dan jijik. Orang-orang yang lebih neurotic cenderung lebih reaktif dan mengikuti perubahan suasana hati yang ekstrim, sementara orang yang kurang neurotic relatif penuh pertimbangan, tenang, tangguh dan kuat. Ekstravensi (Extraversion) mencerminkan tingkat kenyamanan seseorang dengan hubungan. Ekstover bersifat suka bergaul, pandai berbicara, tegas dan lebih terbuka untuk menjalin hubungan baru, sedangkan introver jauh lebih tidak suka bergaul, tidak pandai bicara, tidak tegas dan lebih enggan untuk memulai hubungan baru. Keterbukaan (Openness) mencerminkan ketertarikan luas dan keingintahuan. Mereka bersedia mendengarkan ide-ide baru dan mengubah ide, keyakinan dan sikap mereka sendiri sebagai respon terhadap adanya informasi baru. Keramahan (Agreeableness) menunjukkan kemampuan seseorang untuk bergaul dengan orang lain. Keramahan membawa orang bersikap kooperatif, pemaaf, pengertian dan memiliki sikap yang baik. Kehati-hatian (Conscientiousness) merujuk pada sejumlah sasaran yang difokuskan oleh seseorang. Banyak hasil penelitian yang menunjukkan bahwa orang yang lebih berhati-hati akan berkinerja tinggi dibandingkan dengan orang-orang yang kurang berhati-hati dalam melakukan pekerjaan. Hal ini sangat logis karena orang yang berhati-hati akan bekerja dengan serius dan melakukan pekerjaan dengan cara yang bertanggung jawab.

Al-Dujaily \& Ryu, (2006) dalam penelitiannya menemukan bahwa kepribadian introvert dan ekstrovert mampu mempengaruhi kinerja khususnya dalam system pembelajaran adaptif. Demikian juga penelitian Thoresen et al., (2004) yang menemukan bahwa factor-faktor big five personality secara keseluruhan mempengaruhi kinerja. Hasil yang berbeda ditemukan oleh Nikolaou, (2003) bahwa kepribadian tidak memiliki hubungan dengan variable yang berhubungan dengan kinerja.

Factor lain yang tidak kalah pentingnya dalam mempengaruhi kinerja adalah factor yang berhubungan dengan lingkungan kerja. Hal ini ditegaskan Jason Colquitt et al., (2019) dalam model kinerjanya bahwa secara umum kinerja dipengaruhi oleh empat komponen yaitu organizational mechanism, group mechanism, individual characteristics dan individual mechanism.

Beberapa tahun belakangan muncul kajian yang relatif baru dalam dunia psikologi organisasi yang berfokus pada nilai-nilai spiritual dalam pekerjaan atau yang sering di sebut sebagai spiritualitas di tempat kerja (Agung \& Yogatama, 2015). Pembahasan tentang pentingnya spiritualitas di tempat kerja digagas oleh Maslow (1998) yang menggagas tentang makna hidup dalam dunia kerja. Spiritualitas di tempat kerja kemudian menjadi konsep dalam manajemen dan budaya organisasi. Konsep ini biasa dijelaskan sebagai workplace spirituality atau spirituality in the workplace, kadang juga disebut sebagai spirituality at work dan spiritual workplace, atau spirit at work. Dalam pembahasan ini digunakan workplace spirituality (Prakoso et al., 2018).

Sebagai sebuah konsep baru, spiritualitas di tempat kerja (workplace spirituality) banyak dianggap sebagai bagian dari pengelolaan agama. Hal ini terjadi karena kata 


\section{AkMen

spirituality atau spiritualitas banyak dikaji dalam ilmu teologis berkaitan dengan makna ketuhanan atau keagamaan. Pada dasarnya, semua agama, mengandung ajaran tentang konsep-konsep spiritualitas. Namun demikian, sesunguhnya spiritualitas di tempat kerja tidak ada kaitan dengan pelaksanaan ritual keagamaan. Spiritualitas didefinisikan sebagai kemampuan dasar manusia untuk membentuk makna, nilai, dan keyakinan bagi dirinya dalam menjalani hidup. Spiritualitas memberikan pemahaman tentang nilai-nilai bisa dipegang teguh bersama-sama seperti kejujuran atau integritas, sementara dalam agama ditunjukkan jalan untuk melaksanakannya di tingkat individu (Prakoso et al., 2018).

Ashmos \& Duchon, (2000) mendefinisikan spiritualitas di tempat kerja (workplace spirituality) sebagai pemahaman diri individu sebagai makhluk spiritual yang jiwanya membutuhkan pemeliharaan di tempat kerja dengan segala nilai yang ada dalam dirinya, yang memiliki tujuan dan perasaan bermakna dalam pekerjaannya serta juga mengalami perasaan saling terhubung dengan orang lain dan komunitas di tempatnya bekerja.

Terdapat tiga dimensi spiritualitas di tempat kerja (workplace spirituality) sebagaimana dijelaskan oleh Milliman et al., (2003). Dimensi-dimensi tersebut masingmasing berada pada level individu, level komunitas, dan level organisasi. Dimensi yang pertama adalah yang berada pada level individu yaitu dimensi pekerjaan yang bermakna (meaningful work), yang merupakan aspek dasar dari spiritualitas di tempat kerja yang mana terdiri dari kemampuan untuk merasakan makna terdalam serta tujuan dari suatu pekerjaan, kedua adalah perasaan terhubung dengan komunitas (sense of community) yang beroperasi pada level komunitas, yang mana terdiri dari perilaku manusia yang berfokus pada interaksi antara sesama rekan kerja, dan terakhir yang beroperasi pada level organisasi adalah penegakan nilai-nilai organisasi (alignment with organizational values), merupakan penyelarasaan antara nilai-nilai pribadi karyawan dengan misi dan tujuan dari organisasi.

Penelitian Milliman et al., (2003) menemukan bahwa komponen-komponen spiritualitas di tempat kerja (pekerjaan yang bermakna, perasaan terhubung dengan komunitas, dan penegakan nilai-nilai dalam diri seseorang berkontribusi secara nyata terhadap komponen-komponen pada konstruk perilaku kerja yang dimiliki individu. Penelitian serupa juga telah dilakukan oleh Singh et al., (2016), Tayebiniya \& Khorasgani, (2018), Biswakarma, (2018) dan Badaruddin, (2020) yang menyajikan hubungan yang positif antara spiritualitas di tempat kerja dengan kinerja karyawan. Namun hasil berbeda ditunjukkan oleh hasil penelitian Umam \& Auliya, (2018) yang membuktikan bahwa spiritualitas di tempat kerja tidak memiliki pengaruh yang signifikan terhadap kinerja karyawan.

Berdasarkan pada uraian diatas maka penelitian ini disusun melalui kerangka konseptual sebagai berikut :

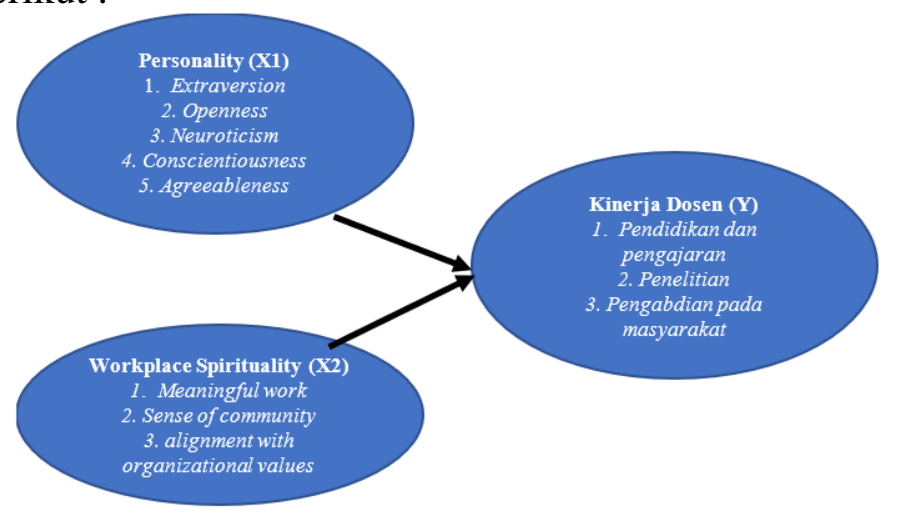




\section{AkMen \\ Volume 18 Nomor 3 Desember 2021 \\ Hal. 234 - 244 \\ e-ISSN : 2621-4377 \& p-ISSN : 1829-8524 \\ Homepage: https//e-jurnal.nobel.acid/index.php/akmen}

Gambar 1. Kerangka Konseptual

Berdasarkan kerangka konseptual yang diuraikan di atas, penelitian ini akan mengembangkan hipotesis sebagai berikut :

1. Terdapat pengaruh positif dan signifikan personality terhadap kinerja dosen di Kota Makassar.

2. Terdapat pengaruh positif dan signifikan workplace spirituality terhadap kinerja dosen di kota Makassar.

\section{METODE PENELITIAN}

Penelitian ini menggunakan pendekatan kuantitatif dan menerapkan penelitian survei untuk mengambil sampel dan menyebarkan kuesioner sebagai alat pengumpulan data. Analisis penelitian ini digunakan untuk menjelaskan (explanatory) hubungan sebab akibat antar variabel secara deskriptif; untuk menguji pengaruh personality dan spiritualitas tempat kerja terhadap kinerja dosen Perguruan Tinggi Swasta di Kota Makassar.

Pengukuran ciri-ciri kepribadian didasarkan pada tes Big Five Personality dan skala terdiri dari 15 item yang berkaitan dengan lima dimensi yaitu : 1) Openness to experience 2) Conscientiousness 3) Extraversion 4) Agreeableness and 5) Neuroticism. Ukuran spiritualitas tempat kerja terdiri dari 12 item yang berasal dari skala pengukuran standar berdasarkan tiga dimensi yaitu : 1) pekerjaan yang bermakna (meaningful work) 2) perasaan terhubung dengan komunitas (sense of community) 3) penegakan nilai-nilai organisasi (alignment with organizational values). Sedangkan pengukuran kinerja dosen terdiri dari 9 item yang berasal dari 3 dimensi kinerja dosen, yaitu : 1) Pendidikan dan pengajaran, 2) Penelitian dan 3) Pengabdian pada masyarakat. Pengukuran dilakukan dengan menggunakan skala Likert 5 poin yang berkisar dari Sangat Tidak Setuju, Tidak Setuju, Kurang Setuju, Setuju, dan Sangat Setuju.

Dalam penelitian ini, seluruh dosen Perguruan Tinggi Swasta di Kota Makassar dipilih sebagai sampel dengan teknik sensus sampling. Jumlah responden ditetapkan dengan berpedoman pada rujukan untuk menilai ukuran sampel dari Hair et al., (2014) bahwa ukuran sampel idealnya harus melebihi 100. Sebagai aturan umum, minimum memiliki lima kali jumlah parameter yang akan dianalisis dan ukuran sampel yang lebih dapat diterima adalah dengan rasio $10: 1$. Berdasarkan pendapat tersebut dan oleh karena dalam penelitian ini menggunakan variabel yang jumlah indikator keseluruhannya adalah 11, maka sampel yang dibutuhkan dalam penelitian ini minimal sebanyak 110 responden. Oleh karena dengan mempertimbangkan dinamisnya responden dan pengujian instrumen penelitian terlebih dahulu, maka dalam penelitian ini seluruh anggota populasi dipilih menjadi sampel.

Untuk mencegah penyebaran pandemi Covid-19 di Kota Makassar, dilakukan survei online. Selanjutnya kuesioner elektronik (google form) dirancang dan disebarkan langsung melalui Whatsapp ke seluruh PTS di Kota Makassar. Pengumpulan data primer dilakukan selama dua bulan, terhitung sejak Juli hingga Agustus 2021. Seluruh ekuesioner yang dikembalikan diverifikasi, dan jumlah responden akhir yang dijadikan data penelitian adalah 178 dosen. Jumlah ini dianggap sesuai karena telah memenuhi syarat jumlah sampel penelitian. Teknik analisis data menggunakan bantuan SPSS. 


\section{HASIL DAN PEMBAHASAN}

\section{Hasil Penelitian}

Pearson Correlation digunakan sebagai alat statistik yang digunakan dalam penelitian ini untuk menguji isi ciri-ciri kepribadian dan spiritualitas tempat kerja serta kinerja dosen. Hasil analisis menunjukkan bahwa semua item kuisioner yang diuji menunjukkan tingkat validitas yang memenuhi syarat. Demikian juga dengan koefisien alfa Cronbach dari kuesioner tentang ciri-ciri kepribadian, spiritualitas tempat kerja dan kinerja dosen dilaporkan masing-masing sebesar 0,665;0,864 dan 0,766, menunjukkan tingkat reliabilitas yang baik.

Ferdinand (2014) menjelaskan bahwa uji F digunakan untuk melihat apakah model yang dianalisis memiliki tingkat kelayakan model yang tinggi yaitu variable-variabel yang digunakan model mampu untuk menjelaskan fenomena yang dianalisis. Layak artinya model regresi yang ada dapat digunakan untuk menjelaskan pengaruh variabel indenden pada dependen. Melalui tabel ANOVA, Model regresi dinyatakan layak apabila nilai $\mathrm{F}$ hitung $>\mathrm{F}$ table dan (Sig.) lebih kecil dari 0,05.

\begin{tabular}{|c|c|c|c|c|c|c|}
\hline \multicolumn{7}{|c|}{ ANOVA $^{a}$} \\
\hline Model & & Sum of Squares & $\mathrm{df}$ & Mean Square & $\mathrm{F}$ & Sig. \\
\hline \multirow[t]{3}{*}{1} & Regression & 1212.481 & 2 & 606.241 & 257.944 & $.000^{\mathrm{b}}$ \\
\hline & Residual & 411.300 & 175 & 2.350 & & \\
\hline & Total & 1623.781 & 177 & & & \\
\hline
\end{tabular}

Berdasarkan data pada table ANOVA di atas, maka terlihat bahwa nilai $\mathrm{F}=$ 257,944, jauh lebih besar dari $\mathrm{F}$ table pada tingkat signifikansi $0 \%$, yang dapat dimaknai bahwa semua variable independent yang digunakan dalam model secara bersama-sama dapat menjelaskan variable dependennya.

Kemudian untuk menggambarkan kemampuan model dalam menjelaskan variasi yang terjadi dalam variable dependen digunakan koefisien determinasi. Koefisien determinasi ditunjukkan dengan angka R Square dalam Model Summary berikut ini.

\begin{tabular}{|c|c|c|c|c|}
\hline \multicolumn{5}{|c|}{ Model Summary } \\
\hline Model & $\mathrm{R}$ & R Square & $\begin{array}{l}\text { Adjusted R } \\
\text { Square } \\
\end{array}$ & $\begin{array}{c}\text { Std. Error of the } \\
\text { Estimate }\end{array}$ \\
\hline 1 & $.864^{a}$ & .747 & .744 & 1.533 \\
\hline
\end{tabular}

a. Predictors: (Constant), Workplace_Spirituality, Personality

Tabel Model Summary tersebut menunjukkan besarnya korelasi atau hubungan (R) antara variable bebas dan variable terikat yaitu sebesar 0,864, yang dapat dikatakan terdapat hubungan antara Personality dan Workplace Spirituality terdahap Kinerja Dosen. Hasil nilai R menunjukkan bahwa hubungan Personality dan Workplace Spirituality 
terdahap Kinerja Dosen di Makassar cukup kuat, hal ini disebabkan nilai koefisiennya berada di atas nilai 0 . Model yang baik menginginkan angka $\mathrm{R}$ yang tinggi.

Dari hasil output tersebut juga diperoleh nilai koefisien determinasi (R Square) sebesar 0,747 yang dapat dikatakan pengaruh variabel bebas yaitu Personality dan Workplace Spirituality terdahap Kinerja Dosen adalah sebesar 74,7\%. Hasil ini menunjukkan bahwa Kinerja Dosen di Makassar dipengaruhi oleh Personality dan Workplace Spirituality sebesar $74,7 \%$ dan $25,3 \%$ dipengaruhi oleh faktor lain selain Personality dan Workplace Spirituality.

Selanjutnya Uji t dilakukan untuk melihat pengaruh variabel-variabel bebas (personality dan workplace spirituality) terhadap variabel terikat (kinerja dosen) secara parsial. Dikatakan variabel independen secara individual berpengaruh signifikan terhadap variabel dependen apabila nilai $\mathrm{t}$ hitung $>\mathrm{t}$ tabel atau nilai signifikansi uji $\mathrm{t}<$ 0,05 .

Berdasarkan hasil uji $\mathrm{t}$ sebagaimana table Coefficients berikut ini, diketahui bahwa nilai $t$ hitung variabel personality (X1) adalah sebesar 3,923 lebih besar dari 1,97 (t hitung $>\mathrm{t}$ tabel) artinya personality secara parsial berpengaruh terhadap kinerja dosen. Untuk variable workplace spirituality, berdasarkan hasil uji t diketahui bahwa $\mathrm{t}$ hitung variable workplace spirituality (X2) adalah sebesar 16,22 lebih besar dari 1,97 (t hitung > t tabel) artinya workplace spirituality secara parsial juga berpengaruh terhadap kinerja dosen.

\section{Coefficients $^{\mathrm{a}}$}

\begin{tabular}{|c|c|c|c|c|c|c|c|c|}
\hline \multirow{2}{*}{\multicolumn{2}{|c|}{ Model }} & \multicolumn{2}{|c|}{$\begin{array}{l}\text { Unstandardized } \\
\text { Coefficients }\end{array}$} & \multirow{2}{*}{$\begin{array}{c}\text { Standardized } \\
\text { Coefficients } \\
\text { Beta } \\
\end{array}$} & \multirow[t]{2}{*}{ t } & \multirow[t]{2}{*}{ Sig. } & \multicolumn{2}{|c|}{ Collinearity Statistics } \\
\hline & & B & Std. Error & & & & Tolerance & VIF \\
\hline \multirow[t]{3}{*}{1} & (Constant) & -4.423 & 2.289 & & -1.933 & .055 & & \\
\hline & Personality & .155 & .040 & .181 & 3.923 & .000 & .680 & 1.471 \\
\hline & $\begin{array}{l}\text { Workplace } \\
\text { Spirituality }\end{array}$ & .628 & .039 & .749 & 16.222 & .000 & 680 & 1.471 \\
\hline
\end{tabular}

a. Dependent Variable: Kinerja_Dosen

\section{Pembahasan \\ Pengaruh Personality terhadap Kinerja}

Merujuk pada hasil analisis dalam penelitian ini, variable kepribadian big five secara empirik berpengaruh positif dan signifikan terhadap kinerja dosen. Temuan ini mengindikasikan bahwa variable kepribadian big five dapat memprediksi dan merupakan predictor yang baik bagi kinerja dosen. Secara teori, kepribadian merupakan bagian yang penting dari seorang pekerja, karena kepribadian merefleksikan bagaimana seseorang bertingkah laku yang pada akhirnya akan memunculkan pola tindakan. Pervin et al., (2010) menjelaskan bahwa kepribadian mempengaruhi pikiran, perasaan, hingga tingkah laku seseorang. Ini menjelaskan bahwa sebuah tugas atau pekerjaan agar menghasilkan kinerja terbaik, harus diberikan kepada seorang pekerja yang memiliki kepribadian yang ideal dengan pekerjaannya.

Dalam konteks hubungan kepribadian dengan kinerja dosen di Makassar, kepribadian yang ditinjau dari aspek Neuroticism menunjukkan bahwa dosen di Makassar relative memiliki stabilitas emosi yang baik, pada aspek Extraversion menunjukkan 
kemampuan dalam membangun hubungan dengan orang lain. Hal ini juga didukung oleh aspek keterbukaan (Openness) dari para dosen untuk bersedia mendengarkan ide-ide baru untuk merespon terhadap adanya informasi baru. Demikian juga sikap keramahan (Agreeableness) dan kesungguhan dalam menjalankan tugasnya sebagai dosen dan melaksanakan pekerjaan dengan cara yang bertanggung jawab (Conscientiousness).

Temuan penelitian ini menunjukkan bahwa dimensi kepribadian mampu mendukung seseorang untuk berhasil dan sukses dalam berkarir dengan menunjukkan kinerja yang baik. Hasil penelitian ini sebanding dan konsisten dengan hasil penelitian Hurtz \& Donovan, (2000) yang menyatakan bahwa kinerja dipengaruhi oleh dimensi kepribadian big five. Selanjutnya Lau \& Shaffer, (1999) juga menunjukkan bahwa kesuksesan karir juga dipengaruhi oleh kepribadian, sejalan dengan temuan Jawahar \& Carr, (2007).

Hasil penelitian yang dilakukan oleh Al-Dujaily \& Ryu, (2006) juga sejalan dengan hasil penelitian ini, yang menemukan bahwa kinerja dipengaruhi oleh kepribadian introvert dan ekstrovert khususnya dalam system pembelajaran adaptif. Demikian juga temuan Thoresen et al., (2004) kinerja secara signifikan dipengaruhi oleh big five personality.

\section{Pengaruh Workplace Spirituality terhadap Kinerja}

Merujuk pada hasil analisis dalam penelitian ini, variable workplace spirituality secara empirik berpengaruh positif dan signifikan terhadap kinerja dosen. Temuan ini mengindikasikan bahwa variable workplace spirituality dapat memprediksi dan merupakan predictor yang baik bagi kinerja dosen. Secara teori, individu sebagai makhluk spiritual, jiwanya membutuhkan pemeliharaan di tempat kerja dengan segala nilai yang ada dalam dirinya, yang memiliki tujuan dan perasaan bermakna dalam pekerjaannya serta juga mengalami perasaan saling terhubung dengan orang lain dan komunitas di tempatnya bekerja (Ashmos \& Duchon, 2000).

Spiritualitas di tempat kerja dibangun oleh indikator yaitu perasaan bermakna dalam pekerjaan (Meaningful Work), perasaan terhubung dengan komunitas (Sense of Community) dan penegakan nilai-nilai (Alignment of Values). Penerapan indikator perasaan bermakna dalam pekerjaan (Meaningful Work) dari variabel spiritualitas di tempat Kerja (Workplace Spirituality) tergambar dari dosen yang merasa nyaman dalam bekerja dan pekerjaan membuat mereka selalu bersemangat, merasakan adanya masa depan yang lebih baik untuk pekerjaan ini dan yang bahwa pekerjaan ini memberikan manfaat untuk orang banyak serta memilki arti penting pada pribadinya.

Untuk penerapan indikator perasaan terhubung dengan komunitas (Sense of Community) dari variabel spiritualitas di tempat kerja (Workplace Spirituality) tergambar dari dosen yang merasakan bahwa mereka saling mendukung dalam bekerja dengan sesama dosen, kemudian merasa bebas mengekspresikan pendapat dalam komunitas dan yang merasakan bahwa rekan sesame dosen saling peduli dengan yang lain serta yang merasakan sebagai satu keluarga dalam komunitas.

Selanjutnya untuk penerapan indikator penegakan nilai-nilai (Alignment of Values) dari variabel spiritualitas di tempat kerja (Workplace Spirituality) tergambar dari nilainilai institusi sejalan dengan nilai-nilai yang yakini oleh dosen, kemudian merasa bahwa institusi memberikan perhatian pada semua dosen dan merasakan bahwa institusi peduli agar para dosen selalu bersemangat dalam bekerja. 
Kondisi hubungan antara spiritualitas di tempat kerja dengan kinerja dosen, dimana penegakan nilai-nilai institusi yang sejalan dengan nilai-nilai yang ada dalam diri dosen dan memiliki tujuan yang sama dengan institusi ternyata merupakan faktor yang menyebabkan meningkatnya kualitas hasil pekerjaan, sehingga secara linier spiritualitas di tempat kerja dapat dikatakan meningkatkan kinerja dosen.

Hasil penelitian ini sebanding dan konsisten dengan hasil penelitian yang dikemukakan oleh Biswakarma, (2018) yang menganalisis hubungan antara menciptakan spiritualitas di tempat kerja, dan bagaimana hal itu memengaruhi produktivitas karyawan di organisasi perhotelan Nepal. Studi ini menyimpulkan bahwa ada hubungan positif antara spiritualitas dan produktivitas kerja serta spiritualitas kerja memprediksi produktivitas karyawan secara positif dalam organisasi perhotelan. Ini menunjukkan bahwa spiritualitas tempat kerja memainkan peran penting untuk membuat karyawan itu produktif dan puas. Dengan demikian karyawan menjadi lebih produktif dalam jangka panjang dibandingkan dengan karyawan dalam organisasi dimana spiritualitas diabaikan atau tidak dihargai.

Begitu juga hasil penelitian Tayebiniya \& Khorasgani, (2018) yang sejalan dengan hasil penelitian ini. Penelitian yang dilakukan untuk menentukan hubungan antara spiritualitas tempat kerja dan kinerja di kalangan Isfahan Staf universitas Islam Azad, menunjukkan bahwa ada hubungan yang bermakna antara spiritualitas tempat kerja, pekerjaan yang bermakna, perasaan terhubung dan hubungan sosial yang positif dengan rekan kerja, keselarasan individu dengan nilai-nilai organisasi dan kinerjanya.

\section{KESIMPULAN}

Merujuk pada hasil penelitian yang telah dikemukakan di atas, maka dapat ditarik kesimpulan sebagai berikut :

1. Personality berpengaruh positif dan signifikan terhadap kinerja dosen. Hasil ini menunjukkan bahwa kinerja dosen dapat ditingkatkan dengan cara meningkatkan kapasitas personality dosen khususnya dalam hal Openness to experience, Conscientiousness, Extraversion, Agreeableness dan Neuroticism.

2. Workplace Spirituality berpengaruh positif dan signifikan terhadap kinerja dosen. Hal ini mengindikasikan bahwa kondisi lingkungan kerja yang mampu menumbuhkan perasaan bermakna dalam pekerjaan (Meaningful Work), perasaan terhubung dengan komunitas (Sense of Community) dan penegakan nilai-nilai institusi yang sejalan dengan nilai-nilai yang diyakini oleh dosen (Alignment of Values) akan berdampak terhadap peningkatan kinerja dosen.

\section{SARAN}

Untuk penelitian lebih lanjut disarankan sebagai berikut :

1. Peneliti selanjutnya dapat menguji pengaruh variable lain yang secara teori juga berpengaruh terhadap kinerja dosen antara lain stress kerja, teknologi, kompensasi dan beberapa variable lainnya.

2. Konsep-konsep atau dimensi-dimensi dari variable personality maupun workplace sipituality yang berbeda dan ter-update, sangat terbuka untuk digunakan dalam penelitian selanjutnya. 


\section{DAFTAR PUSTAKA}

Agung, L., \& Yogatama, M. (2015). Kajian Spiritualitas di Tempat Kerja pada Konteks Organisasi Bisnis. Jurnal Psikologi, 42(1), 1-14.

Al-Dujaily, A., \& Ryu, H. (2006). A Relationship between e-Learning Performance and Personality. Proceedings of the 6th IEEE International Conference on Advanced Learning Technologies ICALT.

Ashmos, D. P., \& Duchon, D. (2000). Spirituality at Work: A Conceptualization and Measure. Journal of Management Inquiry, 9(2), 134-145.

Badaruddin. (2020). Spiritualitas Kerja, Memahami Realitas dan Pengaruhnya (Fatmasari (ed.)). Goresan Pena.

Banfield, S. R., Richmond, V. P., \& McCroskey, J. C. (2006). The Effect of Teacher Misbehaviors on Teacher Credibility and Affect for the Teacher. Communication Education, 55(1), 63-72.

Biswakarma, G. (2018). Impact of Workplace Spirituality on Employee Productivity in Nepalese Hospitality Organizations. Journal of Tourism and Hospitality Education, 8, 62-76. https://doi.org/10.3126/jthe.v8i0.20011

Darman. (2017). Pengaruh Personality, Ability, Dukungan Organisasi, Kepuasan Kerja dan komitmen Organisasi Terhadap Kinerja Dosen Perguruan Tinggi Swasta di Gorontalo. Universitas Hasanuddin.

Ferdinand, A. (2014). Metode Penelitian Manajemen (Edisi Keli). Badan Penerbit Undip.

Hair, J. F., Black, W. C., Babin, B. J., \& Anderson, R. E. (2014). Multivariate Data Analysis Joseph F . Hair Jr. William C . Black Seventh Edition (Seventh).

Hogan, R., Hogan, J., \& Roberts, B. W. (1996). Personality measurement and employment decisions: Questions and answers. American Psychologist, 51(5), 469477.

Hurtz, G. M., \& Donovan, J. J. (2000). 2 Hurtz et al.(2000).PDF. 85(6), 869-879. https://doi.org/10.1037//002I-9010.85.6.869

Jason Colquitt, LePine, J., \& Wesson, M. (2019). Organizational Behavior: Improving Performance and Commitment in the Workplace (6th ed.). McGraw-Hill.

Jawahar, I. M., \& Carr, D. (2007). Conscientiousness and contextual performance: The compensatory effects of perceived organizational support and leader-member exchange. Journal of Managerial Psychology, 22(4), 330-349. https://doi.org/10.1108/02683940710745923

Lau, V. P., \& Shaffer, M. A. (1999). Career success: The effects of personality. Career Development International, 4(4), 225-231. https://doi.org/10.1108/13620439910270607

Mammadov, S. (2021). Big Five personality traits and academic performance: A metaanalysis. Journal of Personality, 0-1. https://doi.org/10.1111/jopy.12663

Manuel, A. M., \& Asuquo, P. N. (2010). University Workers' Perception of Organizational Retirement Plans and Their Attitude to Work. Studies on Home and Community Science, 4(1), 1-9.

Milliman, J., Czaplewski, A. J., \& Ferguson, J. (2003). Workplace spirituality and employee work attitudes: An exploratory empirical assessment. Journal of Organizational Change Management, 16(4), 426-447. https://doi.org/10.1108/09534810310484172

Motowidlo, S. J., Borman, W. C., \& Schmit, M. J. (1997). A theory of individual 
differences in task and contextual performance. Human Performance, 10(2), 71-83.

Neal, A., \& Griffin, M. A. (1999). Developing a Model of Individual Performance for Human Resource Management. Asia Pacific Journal of Human Resources.

Nikolaou, I. (2003). Fitting the person to the organisation: Examining the personality-job performance relationship from a new perspective. Journal of Managerial Psychology, 18(7), 639-648.

Pervin, L. A., Cervone, D., \& John, O. P. (2010). Psikologi Kepribadian (Teori \& Penelitian) (Ed.9). Kencana.

Prakoso, A. R., Susilo, H., \& Aini, E. K. (2018). Pengaruh Spiritualitas di Tempat Kerja (Workplace Spirituality) terhadap Komitmen Organisasional (Studi Pada Karyawan PT. Bank BRI Syariah Kantor Cabang Malang Soekarno Hatta). Jurnal Administrasi Bisnis (JAB), 65(1), 1-8.

Rothman, S., \& Coetzer, E. (2003). The big five personality dimensions and job performance | Rothmann | SA Journal of Industrial Psychology. SA Journal of Industrial Psychology, 29(1), 68-74.

Singh, M. J., Vandana, D., \& Chopra, G. (2016). Relationship among Workplace Spirituality, Work Engagement and Grit. 18(11), 21-27. https://doi.org/10.9790/487X-1811032127

Tayebiniya, N. K., \& Khorasgani, N. S. (2018). The relationship between workplace spirituality and job performance among staff of Azad Islamic University, Iran. Humanities and Social Sciences Reviews, 6(1), 14-19. https://doi.org/10.18510/hssr.2018.613

Tett, R. P., \& Burnett, D. D. (2003). A Personality Trait-Based Interactionist Model of Job Performance. Journal of Applied Psychology, 88(3).

Thoresen, C. J., Bradley-Geist, J. C., Bliese, P. D., \& Thoresen, J. D. (2004). The Big Five Personality Traits and Individual Job Performance Growth Trajectories in Maintenance and Transitional Job Stages. Journal of Applied Psychology, 89(5).

Umam, M. R. K., \& Auliya, Z. F. (2018). Hubungan Kausalitas Workplace Spirituality Dan Kinerja Karyawan: Perspektif Mediasi Etika Kerja Islam. BISNIS : Jurnal Bisnis Dan Manajemen Islam, 5(1), 23. https://doi.org/10.21043/bisnis.v5i1.2946 